\title{
Science Education for Citizenship: A Case Study ${ }^{1}$
}

\author{
Muhammet ÖZDEN²
}

Submitted by 10.09.2019

Accepted by 22.01.2020

Research Paper

\begin{abstract}
The aim of this study is to discover the topics/contexts covered in the science course with respect to citizenship education. This study was carried out using a case study design, a qualitative research approach. Since this study was designed as a case study, the primary data collection technique was the participant observation technique. Critical case sampling was used to collect qualitative data during the observations. The observational data were obtained from two classes in 2009 during the fall semester. Also, several semi-structured interviews were conducted with the teachers in 2010 during the spring semester to support observation data and increase the credibility of the study. Criterion sampling was used to determine the teachers to enroll in the study, and a total of 24 teachers participated in the interviews. The study data were analyzed through content analysis. In the content analysis, a conceptual framework was formed in light of the literature on the relationship between citizenship education and citizenship education within a science course. The coding stage in this study was based on this conceptual framework. The results showed that, as a part of citizenship education, science course could deal with the topics of ScienceTechnology-Society-Environment, Scientific Literacy, Socio-Scientific Issues, Rights and Duties.
\end{abstract}

Keywords: Science education, science for citizenship, science-technology-society-environment, socioscientific issues, scientific literacy

\footnotetext{
${ }^{1}$ This study was prepared based on a doctoral dissertation entitled the Functionality of Science and Technology Course with respect to Citizenship Education. Ethics committee permit was obtained from Eskişehir Provincial Directorate of National Education for this research with the number of B.08.4.MEM.4.26.00.02.310 dated 07.12.2009.

2 Kütahya Dumlupınar University, Education Faculty, Department of Primary Education, e-mail: muhammetozden@gmail.com, ORCID: 0000-0003-4325-0803
} 
AJESI - Anadolu Journal of Educational Sciences International, 2020; 10(1): 150-188

DOI: 10.18039/ajesi.682020

\section{Introduction}

Citizenship education is considered to be more than an academic discipline (Chamberlin, 2003) and has been accepted as one of the main objectives of educational activities (Anderson, Avery, Pederson, Smith \& Sullivan, 1997). Citizenship education can be defined as a process which intends to educate students about the subjects that affect today's societies and gradually progress in the historical process such as state administration, laws and policies (Hoge, 2002). According to another definition, citizenship education is the process of students' acquisition of social and moral responsibility, social participation, and political literacy (Qualifications and Curriculum Authority-QCA, 1998). Based on these definitions, the aim of citizenship education is to cultivate students with effective citizenship skills (Hicks, 2001; Hoskins, 2006; Nelson \& Kerr, 2006).

Citizenship education has been implemented in various ways including (i) citizenship education through curricula, (ii) citizenship education through cross-curricular/noncurricular activities, (iii) citizenship education through links between school and society, and (iv) citizenship education through school culture. (Birzéa, Kerr, Mikkelsen, Froumin, Losito, Pol, Sardoc, Harrison \& Baumgartl, 2004; Ersoy, 2007; Kerr, Keating \& Ireland, 2009; Nelson \& Kerr, 2006). In the primary education programs implemented between 2005 and 2013 in Turkey, citizenship education was a required course. However, citizenship education has ceased to be a required course and taken place as "human rights and citizenship" interdisciplinary topic in different courses. In this context, it can be said that citizenship education approaches have been adopted through cross-curricular/extracurricular activities in Turkey. According to this approach, citizenship education is not in the responsibility of a single course, and extracurricular activities can be organized to support citizenship education. The adoption of such an approach requires the development of an interdisciplinary approach among curricula. Accordingly, objectives of citizenship education have been identified and 
AJESI - Anadolu Journal of Educational Sciences International, 2020; 10(1): 150-188 DOI: 10.18039/ajesi.682020

efforts have been initiated to make contributions to the citizenship education via each course in the program (Ersoy, 2007). For example, Özden and Yaşar (2009) reported that 37 of the learning outcomes in the $4^{\text {th }}$ and $5^{\text {th }}$-grade science and technology curriculum were related to citizenship education. Researchers identified such learning outcomes related with citizenship education in science courses including "can able to know renewable and non-renewable energy sources and their importance., can able to know that individuals and society are responsible for protecting the environment and wildlife., can able to recognize and understand the impact of technology on the environment., can able to understand that science and technology applications can have positive or negative effects on individuals, society and environment." (Özden \& Yaşar, 2009).

Certainly, citizenship education is not the main purpose of science education. However, all courses in the program are expected to undertake a responsibility to carry out citizenship education with an interdisciplinary approach in the contemporary understanding of citizenship education. On the basis of this view is the idea that the primary purpose of the education system and schools are citizenship education. However, at this point, it is necessary to examine and determine the functions of courses in the programs and their contributions to citizenship education. This also applies to science courses, which are expected to play critical roles in acquiring citizenship competencies. For this purpose, it is essential to examine why the science and technology course takes responsibility for citizenship education and how it can fulfill this responsibility through a teaching-learning process.

\section{Literature Review}

Research suggests that science and citizenship education can be integrated (Davies \& Thorpe, 2003; Duggan \& Gott 2002; Osborne, 2000). Skills to keep up with the social implications of science, to reason and to make informed decisions are the basic qualities 
AJESI - Anadolu Journal of Educational Sciences International, 2020; 10(1): 150-188

DOI: 10.18039/ajesi.682020

needed by citizens to make ethical choices. These requirements are believed to be attained by means of the integration of science and citizenship education (Davies, 2004; Levinson \& Turner 2001; Ratcliffe \& Grace, 2003).

Having emerged as a new point of view of science education, "Science-TechnologySociety (STS)" approach (Zembylas, 2005) tries to discover and understand both how science and technology shape contemporary culture, values and institutions and how contemporary values shape science and technology (Mansour, 2009). Rather than ignoring ethical considerations in science education, the aim of STSE topics is to support active citizenship by letting students discover social problems based on science such as global warming, deforestation, modifying the human genome, managing fish stocks and so on (Blades, 2006). Therefore, the aim of this approach is to educate students as knowledgeable and responsible citizens by emphasizing the relationship between technology, society and environment and socio-scientific subjects in curricula (Solomon, 1993). In a broader sense, science-technologysociety-environment education can be considered as citizenship education because both science education for citizenship and STSE approach emphasize issues about making individual and social decisions (Ratcliffe \& Grace, 2003). Such an educational approach might empower students as citizens (Kolstø, 2001).

STSE educators advocate that individuals should be equipped with literacy within the context of individual and social responsibility and ethics (Aikenhead, 1990; Pedretti, 1999; Solomon, 1993). STSE curricula are designed and developed to interpret the scientific and technological phenomena integrated with social structure. In this sense, the aim of STSE curricula is to educate citizens with the ability to understand scientific, technological, social and environmental issues by developing critical, scientific and technological literacy, supporting reasoning and decision-making about these issues, and ensuring that individuals take action in accordance with their decisions (Mansour, 2009). 
AJESI - Anadolu Journal of Educational Sciences International, 2020; 10(1): 150-188

DOI: 10.18039/ajesi.682020

Socio-scientific issues (SSI) can be defined as a concept used to describe the important social issues and problems which are closely related with science in conceptual terms (Sadler, Barab \& Scott, 2007) or an issue which is complex, open-ended, usually in the form of complex dilemmas and does not have a definitive answer (Sadler, 2004). SSI reflect the scientific and technological developments in industrialized countries. Genetically modified crops (Bottcher \& Meisert, 2013), genetic engineering, water fluoridation (Khishfe, 2014), global warming, alternative fuels, stem cells, genome projects and cloning (Sadler, 2004) are common SSI that society has confronted and asked to make decisions. SSI are to help students develop skills, such as discussion, argumentation, and informed decision-making which are important competencies for them to take standpoints in daily life (Ideland, Malmberg, \& Winberg, 2011) as citizens. Individuals and society are obliged to make personal and ethical decisions about socio-scientific issues based on the information they acquire through the press and the media. Recent developments in science and technology lead to the emergence of situations that create a dilemma for society. Solutions to situations that create dilemmas depend not only on scientific knowledge but also on moral and ethical values (Levinson \& Turner, 2001; Ratcliffe \& Grace, 2003). In this regard, what is aimed by the inclusion of SSI in science curricula is to establish a relationship between social justice and the content of science course (Solomon, 1993) and to provide opportunities for individuals to contribute to the solution of social problems by means of their values and knowledge. Therefore, SSI need to be utilized in science courses in order to prepare students for citizenship education. This is because research suggests that SSI can be a means in promoting democratic citizenship through science education (Zeidler, Sadler, Simmons, \& Howes, 2005 in Cajas, 1999). In this sense, educators of science can achieve the objective of educating knowledgeable and responsible citizens who can think logically by covering SSI in science course (Driver, Newton, \& Osborne, 2000; Sadler, 2004 in Kolstø, 2001). 
AJESI - Anadolu Journal of Educational Sciences International, 2020; 10(1): 150-188

DOI: 10.18039/ajesi.682020

The idea of citizenship education in science has often been conceptualized and defended within the framework of scientific literacy (Hurd, 1998; Lee \& Roth, 2003) because the qualities to be possessed by scientifically literate individuals emphasize responsible citizenship (Bingle \& Gaskell, 1994; Jenkins, 1992; Layton, Jenkins, MacGill \& Davey, 1993). Scientific literacy ensures that science and technology are used to educate individuals as conscious citizens in order to solve global challenges facing humanity today (Roth \& Dêsautels, 2004). For this reason, in terms of citizenship education, it is essential that science classes emphasize the concept of "scientific literacy", the nature of scientific knowledge and the decision-making process related to scientific issues (Barbosa, 2004).

The notion of scientific literacy of citizens can be conceptualized as the level of understanding about science and technology that is required to act as citizens in contemporary industrialized societies. The level of understanding in this conceptualization refers to the minimum level of scientific literacy required for any citizen rather than an ideal level. There are two dimensions of scientific literacy. These are knowing the basic scientific terms and concepts and understanding scientific methods and the processes in examining reality. Since the two dimensions are strongly interrelated, citizens are expected both to understand the basic approach of science and to develop a logical understanding related to the current public policies which include subjects of science and technology (Miller, 2006). If students are expected to become citizens who make decisions about science-related individual and social problems that they might face in the future, it is crucial that they develop an understanding of science. Such decisions involve an elaborate evaluation of scientific claims which provide strong connections among evidence, inferences, and results. Students' competence to make such decisions indicates their level of functional scientific literacy (Zeidler, Sadler, Simmons, \& Howes, 2005). Science education curricula should equip students with enough scientific knowledge and understanding to read simple news about science in a newspaper or watch a 
AJESI - Anadolu Journal of Educational Sciences International, 2020; 10(1): 150-188

DOI: 10.18039/ajesi.682020

television show about the latest scientific advances. Such an educational approach will allow students to express their opinions on important social and ethical issues which they might encounter in their lives as adults (Millar \& Osborne, 1998 in Hodson, 2003).

The importance of science education courses is increasing because they are supposed to play a key role making science and technology a natural part of everyday life, individuals understand individual and social changes and participate effectively in society by recognizing their rights and responsibilities in the changing social conditions. This is because advances in science and technology today have significantly affected the lives of individuals and societies. In addition, citizens should have sufficient knowledge, understanding, and values so that they can keep up with scientific and technological advances and use science and technology effectively. Thus, it could be suggested that science and technology have an important role in ensuring citizen participation in the growth and development of education. If science education is assigned an important responsibility for citizen participation in the process of growth and development, the perception of the nature of science education should change and science education should not be seen as pure "science". Science course should be integrated into a dynamic learning environment where students gain awareness on science and technology-based social issues, take part in in-class discussions about science and technologybased current problems, evaluate different views critically and utilize their scientific process skills to analyze various topics and issues presented in the classroom. Students need to understand the interaction of science and technology with the environment and society and employ their knowledge, understanding, and skills when looking for solutions to problems. It is vital that students regard science and technology within this broader context and, as a result, learn how to relate their knowledge of science and technology to the world outside of school. In order to achieve this goal, it is necessary to adopt a notion of education designed 
AJESI - Anadolu Journal of Educational Sciences International, 2020; 10(1): 150-188

DOI: 10.18039/ajesi.682020

with such a philosophy and to carry out studies to design and improve curricula in line with that objective.

In recent years, there have been suggestions about the need for implementing citizenship education by means of all courses. As this approach is adopted more and more, there is an increasing effort to connect many courses to citizenship education and determine the existing applications. However, there is not much research about the relationship between science course and citizenship education. An examination of existing studies, on the other hand, shows that the relationship between science education and citizenship education has mostly been discussed at a theoretical level. The relevant literature usually focuses on the reason why science and technology course should undertake responsibility for citizenship education, how it will fulfill this responsibility and what kind of a teaching-learning process should be employed in this process (see Millar \& Osborne, 1998; Osborne, 2000; Ratcliffe, \& Grace, 2003). On the other hand, investigating the value of these theoretical suggestions in practice, analyzing how citizenship education is put into practice by means of science and technology course and determining teachers' opinions concerning this process seem to be important in scientific terms. This is because the results to be obtained and the recommendations to be made based on these results will derive from scientific data and, therefore, this might make the process of establishing a relationship between science and technology education and citizenship education more reliable and valid. In this regard, the aim of this study is to discover the topics/contexts covered in the science course with respect to citizenship education. For this purpose, the following sub-problems were created:

1. What topics/contexts do citizenship education take place in $4^{\text {th }}$ and $5^{\text {th }}$ grades in science and technology courses?

2. What are classroom teachers' views on the characteristics of citizenship education in science and technology courses? 
AJESI - Anadolu Journal of Educational Sciences International, 2020; 10(1): 150-188

DOI: 10.18039/ajesi.682020

\section{Method}

\section{Design}

This study was carried out using case study, a qualitative research approach. In case study, a current phenomenon is examined in its natural context and by using many data sources (Yin, 2003). According to the literature, case study designs are categorized in several ways. This study is defined as an embedded single case study according to Yin's (2015) categorization but as a collective case study according to Stake's (1995) categorization. The embedded single case study design can have more than one substrate or unit within a single case. In this case, more than one sub-unit can be in a case (Yıldırım \& Şimşek, 2006; Yin, 2003). Similarly, multiple/collective case studies are studies that cover a large number of cases to learn more about a phenomenon, people community, or a general situation (Stake, 2005). Multiple/collective case studies are research studies conducted on a large number of cases in which both cases are examined individually and all of them crosswise (Punch, 2005). As can be seen, embedded single case studies and collective case studies can be used to study multiple cases. However, multiple case differences in the research context are not taken into account in Stake's (1995) classification and case studies in multiple research settings, regardless of the research context, are called collective case studies. On the other hand, Yin's (2015) classification contains the desire to analyze the contextual conditions related to the case being examined. Furthermore, Yin's (2015) classification argues that single- and multicase studies reflect different design situations and that there may be unitary or multiple analysis units within these two variants. In this study, the sub-units of the embedded single case design were the students in the $4^{\text {th }}$ and $5^{\text {th }}$ Grades in a state-funded primary school. Therefore, observation data were collected from two different classroom environments and there are multiple units of analysis. In addition, the spiral design of the Curriculum of Science 
AJESI - Anadolu Journal of Educational Sciences International, 2020; 10(1): 150-188

DOI: 10.18039/ajesi.682020

Course for Primary $4^{\text {th }}$ and $5^{\text {th }}$ Grades (Ministry of National Education [MoNE], 2005) required the use of this design because the content in both grade levels are similar and, due to their spiral designs, they supplement each other. Thus, examination of the wholeness caused by the curriculum by means of the (Type 2) single-case (embedded) designs emerged as a requirement.

\section{Participants}

The participants in this study were the teachers and students at a public school in western Turkey. Multiple sampling strategies were adopted to identify the possible participants for the study. Since this study was designed as a case study, the primary data collection technique was the participant observation technique (Yıldırım \& Şimşek, 2006). Critical case sampling was used to collect qualitative data during the observations (Yildirım \& Şimşek, 2006). The observational data were obtained from two classes of the school: 4/C, a $4^{\text {th }}$ Grade class, and, 5/A, a $5^{\text {th }}$ Grade class. The teacher of 4/C was a 43-year-old female teacher who had graduated from College and had been a primary school teacher for 21 years. The teacher of 5/A was a 50-year-old female teacher who had graduated from a Teacher Training Institute and had been a primary school teacher for 29 years.

Also, several semi-structured interviews were conducted with the teachers to support observation data and increase the credibility of the study. Finally, criterion sampling (Patton, 2001) was used to determine the teachers to enroll in the study. A total of 24 teachers, 13 females and 11 males, participated in the interviews. Among the teachers, four were 26-35 years old, 11 were $36-45$ years old, seven were 46-55 years old and two were 56 years old or older. Among the teachers, 11 taught $4^{\text {th }}$ graders and 13 taught $5^{\text {th }}$ graders.

Among the students, 33 were $4^{\text {th }}$ graders -14 females and 19 males - and 35 were $5^{\text {th }}$ graders -10 females and 25 males. Among the $4^{\text {th }}$ graders, six were 10 years old or younger 
AJESI - Anadolu Journal of Educational Sciences International, 2020; 10(1): 150-188

DOI: 10.18039/ajesi.682020

and 27 were 11 years old. Among the $5^{\text {th }}$ graders, 28 were 11 years old and seven were 12 years old or older. In terms of the academic achievement level among the $4^{\text {th }}$ graders, eight students were in $85-100$ score interval, 11 were in the 70-84 interval, nine were in the 55-69 interval and five were in the 45-54 interval. Finally, in terms of the academic achievement level among the 5th graders, 10 students were in $85-100,17$ were in $70-84$, three were in 5569 and five were in 45-54 score intervals.

\section{Data Collection}

The primary data collection technique in case studies is participant observation (Stake, 1995, 2005; Yıldırım \& Şimşek, 2006; Yin, 2003). Participant observation technique was the primary data collection technique in this study, too. The observational data were collected in "Let's Solve the Puzzle of Our Bodies" and "Introduction to Matter" units in $4^{\text {th }}$ grade Science and Technology course and in "Let's Solve the Puzzle of Our Bodies" and "Change and Recognition of Matter" units in $5^{\text {th }}$ grade Science and Technology course in the fall semester of 2009 during 38 hours and 30 minutes. Because it was not possible to collect observational data in the other units of the textbooks and due to time and cost constraints, it was decided to conduct interviews with teachers from different schools so that an overall evaluation about the situation could be made about the case in question. For this purpose, several semi-structured interviews were conducted with teachers apart from those involved in the case. In case studies, interviews are used to detect that cannot be observed by the researcher used for the detection of unobservable events. In this way, case studies could involve others' descriptions and interpretations as well because a situation might not be regarded in the same way by everyone (Stake, 1995). In the light of these considerations, the semi-structured interviews in this study were conducted with the primary school teachers to understand how the case in question is described and interpreted by different teachers, to 
AJESI - Anadolu Journal of Educational Sciences International, 2020; 10(1): 150-188

DOI: 10.18039/ajesi.682020

determine the opinions of a large group of participants about the case, and to support, check and verify the observation data in the spring semester of 2010. Ethics committee permit was obtained from Eskişehir Provincial Directorate of National Education for this research with the number of B.08.4.MEM.4.26.00.02.310 dated 07.12.2009.

\section{Data Analysis}

The study data were analyzed through content analysis (Miles \& Huberman, 1994; Yıldırım \& Şimşek, 2006). The primary objective of content analysis is to obtain the concepts and relationships that can account for the data collected (Yıldırım \& Şimşek, 2006). In this regard, in the content analysis, the data collected were conceptualized first, the emerging concepts were arranged in a logical way then and the themes were identified finally. In the analysis stage, the similar data were grouped within certain concepts and themes and they were arranged and interpreted in a way that is comprehensible to readers.

The data in this study were collected through observations and interviews. The analysis stage for the qualitative data collected included coding the data, identifying the themes, arranging the codes and themes, and describing and interpreting the results. The coding stage in this study utilized a coding approach based on an overall framework (Y1ldırım \& Şimşek, 2006). In this regard, a conceptual framework was formed in light of the literature on the relationship between citizenship education and citizenship education within science course. The coding stage in this study was based on this conceptual framework. In addition, the new codes which emerged during the analysis stage were added to the existing list of codes or some codes were eliminated from the list. Once the data collected were coded, the structures or themes in other words, which could provide a general account of the codes and group them under certain categories were determined. To determine the themes, the codes were grouped together and examined first. Some commonalities were sought among the 
codes, which could be considered as a thematic coding process. The collected data were categorized by means of the codes. After the thematic coding stage, the data were arranged according to the codes and the themes identified. By means of the detailed coding at the beginning and the thematic coding as the second step, the researcher formed a system in which the collected data could be categorized. As the third step, the researcher categorized the data obtained through this system and identified and interpreted the data based on certain phenomena. The data were defined, explained and presented in clear and unambiguous terms so it can be understood by the average reader. Also, the researcher presented the collected data in a processed format but without adding the researcher's own opinions and comments.

As the last step of the data analysis stage, the researcher interpreted the data to obtain some results. To make the data clearer and more meaningful, the researcher explained the relationships between the findings, established cause-effect relations and made explanations regarding the significance of the findings by inferring some implications out of them.

\section{Results}

A total of four themes were formed in the light of the qualitative data obtained from the study: Science-Technology-Society-Environment, Scientific Literacy, Socio-scientific Issues, Rights and Duties. The organization of themes can be seen in Figure 1 below.

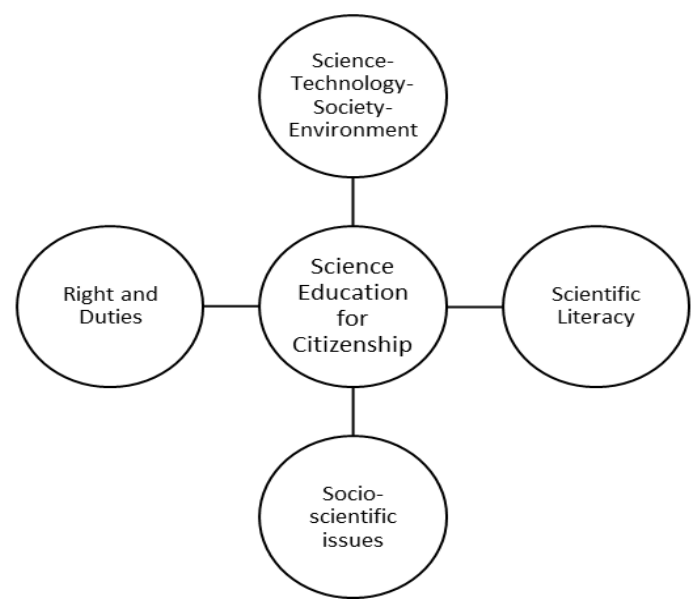

Figure 1. Themes for science education for citizenship 
AJESI - Anadolu Journal of Educational Sciences International, 2020; 10(1): 150-188

DOI: 10.18039/ajesi.682020

\section{Science-Technology-Society-Environment}

In relation to Science-Technology-Society-Environment (STSE) theme, the teacher provided students with information about developing awareness about the impact of technology and people on the environment. While presenting the topic of natural, processed and artificial matters in $4^{\text {th }}$ Grade Science unit "Introduction to Matter", the teacher explained that people made changes on the natural environment and we should be concerned about the environment. The teacher said, “...so you should be sensitive about the environment. We are different from prehistoric people because we do live in a few things. According to the conditions of the era we live in now, we have to care for everything around us in a more sensitive way and use everything more attentively and carefully. This is because we've already started to affect the environment, haven't we?"

Teacher: They are consumed and thrown away into the environment. In this way, we both pollute the environment and cut down trees and so we are preventing the places where we live from becoming more clean and healthy. To say the least, you'll care about everything you use daily. You will pay much attention to your books, notebooks, belongings, tools and everything in the environment where you live. For example, disposable cups are made of plastic, glass, paper. What should we do with them when we are finished with them? Should we throw them in the trash or what?

Students: We should throw them into the recycling containers.

This teacher emphasized the exhaustible nature of resources in nature. In this regard, the teacher stated that individuals must respect the natural environment and pointed out that people should consume no more than they need. Furthermore, the teacher stressed the need for sorting recyclables based on their properties and using recycling containers in terms of preserving the natural environment. Regarding the importance of recycling, the teacher said, "Recycling bins are there for you... for your future. They are there so that you can live in a 
AJESI - Anadolu Journal of Educational Sciences International, 2020; 10(1): 150-188

DOI: 10.18039/ajesi.682020

clean and healthy future. That's why you'll be sensitive. And you will teach the people around you what to do with them. You are supposed to teach as well when necessary."

The lesson unit "Introduction to Matter" in $4^{\text {th }}$ Grade science course deals with the key features of solids, liquids, and gases. With respect to the properties of gases, the students explained that gases can be compressed, and deodorants are produced in this way. In this context, the issue of global warming was discussed in the classroom. The teacher explained to the students that there are various causes of global warming and the greenhouse effect; the carbon-containing gases used in refrigerators at home damage the gas layers in the atmosphere gases in the atmosphere and negatively affect its function of filtering harmful rays; plants, animals, and humans are negatively affected by this situation; with the increasing industrialization and technological production, these developments have negatively affected the health of the world over the last 20-30 years; especially in the polar points, in areas where the ozone layer is thinner, harmful rays reach the world; various diseases, mainly cancer, arise as a result of these; not only people but animals and plants are also affected by this situation, and human beings are required to take measures to prevent this situation.

The unit "Introduction to Matter" in $4^{\text {th }}$ Grade science course also deals with the impact of human beings on the natural environment. In this regard, the teacher reminded the students a documentary they watched in the previous years, Life After People, and explained that when people do not interfere with nature, nature is able to renew itself. The teacher mentioned the transformation of nature following the explosion of the Chernobyl nuclear power plant as an example and explained that despite the Chernobyl catastrophe, nature can renew itself without the human impact. The teacher emphasized that people should respect nature. The conversation between the teacher and the students on the subject are as follows:

The teacher: You watched a movie last year: Life After People... What did you notice in that movie? How did nature behave when there were not any human beings around? 
AJESI - Anadolu Journal of Educational Sciences International, 2020; 10(1): 150-188

DOI: 10.18039/ajesi.682020

A student: It was green everywhere.

A student: nature was all green.

The teacher: Well, what about the traces of people? Did they remain?

The students: No...

A student: Because people always harm nature. For example, there was a football pitch in the movie. When there were no longer people around, it was green again as nature flourished freely.

The teacher: Yes. That is a good example. The most recent example was the Chernobyl Catastrophe. After the incident in that city in Ukraine, despite the high level of radiation, nature repaired itself so beautifully when there was no human intervention... What did nature do? It repaired itself. This means that the species that destroys nature is human beings. This means that people should respect the environment.

The teacher explained that human beings treat the nature disrespectfully, exhaust the natural resources unconsciously and their consumption habits harm the natural environment and said, "We mistreat nature. We eat and consume unconsciously. We are never satisfied with our clothes, shoes, furniture at home and so on..." Turkish course was utilized to describe the relationship among STSE topics in the $4^{\text {th }}$ Grade science course. As a part of Turkish course, the students watched a documentary, Home. As a learning tool, the documentary provided the students with information about the effects of human activities on our environment and ecosystem. Another aim of the documentary was to have students develop an understanding of the relationship between the animate and inanimate things and learn about global environmental problems.

The discussions in the semi-structured interviews centered on educating and informing students as a part of environmental education in relation to the STSE theme, scientific and 
AJESI - Anadolu Journal of Educational Sciences International, 2020; 10(1): 150-188

DOI: 10.18039/ajesi.682020

technological inventions, the effects of scientific and technological developments on the life of the individual and society, promotion students' interest in scientists and their lives. Within the STSE theme, most of the participants stated that students should be educated about improving and protecting the natural environment and that citizenship education in science course should deal with issues such as protection of the natural environment, environmental pollution, water pollution, air pollution, erosion, conservation of species in the nature, recycling, underground and surface sources and global warming. For example, Yağmur said, "The subjects about citizenship usually deal with the environment and sensitivity about environmental issues... what should a good citizen do? A good citizen should use resources efficiently, in an economical way... In the unit Light and Sound, for example, we discussed the harmful effects of light pollution on our environment, to the country's economy, to ourselves, to all beings." As Yağmur stated, the topics related to citizenship education in science course tend to be presented within subjects on environmental education and associated with environmental awareness.

Another teacher, Meryem, stated that with respect to citizenship education, science course examined the impact of negative changes in the natural environment on individuals' lives and said, "How do we protect our environment? The negative effects of the environment on human health... The human impact on the environment. We're trying hard to establish the link between the two." The teacher explained that science course, in this sense, had students think about the possible consequences of the changes due to human-induced factors in their natural environment, think about the possible consequences of human activities with the development of discussion and reasoning skills, and take action effectively. Similarly, another participant stated that some problems arose due to the unconscious and irresponsible use of nature by people and, with respect to citizenship education, science course should inform students about the consequences of human activities. Within the theme of STSE, the 
participants also drew attention to the impact of scientific and technological developments on the individual, the society, and the environment. Özgür made a comprehensive statement:

It is necessary to know about laws and regulations, but there are the laws and rules of nature before the laws and rules which we set. This is relevant to science. People who know the laws and rules presented in Social Studies course become good citizens. Well, what are the rules and laws of nature? They are the rules and laws of science. If you violate the rules of nature, future generations become extinct. .... When you go against the rules and laws of nature, you destroy all of humanity. ... The subjects of science include all the universe and the world. If students do not become conscious citizens in the science course, any mistake they might make goes beyond their own country. ... Science concerns all beings, the whole world. I mean science is essential for global citizenship.

Emphasizing the structure of natural functioning through certain principles and rules, Özgür stated that it was crucial to raise awareness of these principles and rules within the scope of citizenship education. He believed that the consequences of unconscious behavior of individuals about issues requiring knowledge of science and technology affected the whole world and, for this reason, it was important that education makes individuals citizens who were globally active, informed and responsible about science and technology. Özgür also mentioned the distinction between social studies course and the meaning attributed the concept of citizenship in science course. He thought the aim of citizenship education in social studies was to teach about the ideals of democratic life such as social justice, equality, and human rights, in other words, to give people awareness of democracy; democratic values could be taught by addressing some issues in the classroom such as racism, gender discrimination, social class distinctions, and inequality; the aim of citizenship education within science course was to help individuals make decisions about their own lives based on 
AJESI - Anadolu Journal of Educational Sciences International, 2020; 10(1): 150-188

DOI: 10.18039/ajesi.682020

scientific knowledge and understand how scientific policies for public benefit were arranged and how these policies affected their lives; the basic tool of citizenship education in science course was scientific and technological phenomena; and, therefore, citizenship education in science course was required to support scientific freedom, to share scientific responsibility and to organize, use and interpret scientific knowledge in social structure.

With respect to citizenship education in science course, the participants drew attention to the need for the assessment of positive and negative effects of scientific and technological advancements on individual and social life and stated that the aim of formal education was to inform students about the proper use of scientific and technological innovations. For example, Ayten thought that scientific developments had adverse effects on social life although they made life easier. Ayten argued that individuals needed to be critical about the effects of science on social life and said, "science course should show us that science might damage and complicate life while it makes life easier for us. What science offers might cause trouble in the future. In fact, it has already started to cause damage to health and the environment." Ayten thought that science and technology were negatively affecting areas of life such as the environment and health more and more and, therefore, students should be educated in a way that they could recognize the adverse effects of science and technology as well as the positive ones.

\section{Socio-Scientific Issues}

The observations in $4^{\text {th }}$ and $5^{\text {th }}$ Grades science course showed that socio-scientific issues were utilized in the teaching-learning process. For example, the pandemic influenza known as swine flu was discussed in both grade levels. The lesson unit "Let's Solve the Puzzle of Our Bodies" in $4^{\text {th }}$ Grade science course deals with respiratory organs and correct breathing. The teacher said that one should be careful around sick people to be healthy, 
AJESI - Anadolu Journal of Educational Sciences International, 2020; 10(1): 150-188

DOI: 10.18039/ajesi.682020

warned the students about the swine flu epidemic and to be alert during contact with other people, and advised them to be more careful in mass diseases and to take plenty of fluids to avoid diseases.

The teacher and students expressed their views on the current issue of swine flu. While the issue of swine flu disease disturbed both the teacher and students as a socio-scientific issue, they were not able to achieve consensus on the source of and solution to the problem, which is just another example showing that socio-scientific issues are often controversial issues. On the other hand, the students expressed their reservations about swine influenza vaccination and shared what they learned from various sources with the teacher and their classmates. The teacher stated that there was no consensus about whether vaccines were necessary or not and the Ministry of Health did not provide the public with any sufficient and convincing information. The teacher added that the students needed to have knowledge as individuals and to act regarding decisions based on scientific knowledge and said:

... you should watch the news on TV very carefully. You should follow local newspapers and national newspapers very closely. We need the information to make a comment. We cannot interpret without knowledge. Making assumptions does not provide any benefits for you or for the country. Then you should obtain information and think about it critically. Watch the national TV channels with your families, note interesting events and share them in the classroom with us. Let's discuss it together. You need to base your comments on knowledge.

As a part of $4^{\text {th }}$ Grade science course, the students talked about their conversations with their families about the swine flu vaccine. The teacher asked the students questions about their conversations with their parents about the swine flu and the students shared what their families thought about the issue. The controversy about the necessity of the swine flu vaccination was discussed extensively in the lessons and the students' comments showed that 
AJESI - Anadolu Journal of Educational Sciences International, 2020; 10(1): 150-188 DOI: 10.18039/ajesi.682020

their parents held opposing views about the issue. Some of the parents believed their children needed to be vaccinated against the swine flu while some others warned their children not to take the vaccine. After talking with almost all of the students about their views on the subject, the teacher also made comments on the subject. The teacher mentioned the effects of pandemics such as the swine flu on social life and shared with the students the statement made by the Ministry of Health, the competent public authority on the subject. The teacher's inclusion of the swine flu in the teaching-learning process as a socio-scientific topic and explanations about the subject were important as the teacher addressed the need for individual knowledge and making informed decisions and preferences in decision-making processes about socio-scientific issues in terms of citizenship education.

After the observation sessions, the researcher asked the teacher why the views of parents regarding the swine flu vaccination was discussed in the classroom. The teacher's response was recorded in the research journal; the teacher said:

Parents watch TV news that is relevant to them. They make comments on events in Turkey. My purpose here is to encourage parents to investigate a specific subject. I intend to help them investigate any subject and make informed decisions when making decisions about themselves and their children. I myself have questions, too. Personally, for the time being, I am suspicious about it [vaccination] but I think I'll use it because people I trust give positive feedback and research provides positive results. It is a matter of health after all. Are parents investigating the subject or not? That's important because it will be an advantage for me if parents are conscious. What is learned in the classroom could influence them in a positive way. This is about being an informed citizen. At this point, parents' education is important.

The teacher thought that discussing parents' views on socio-scientific issues was a way of involving parents in education through students. The teacher also said that parents' 
AJESI - Anadolu Journal of Educational Sciences International, 2020; 10(1): 150-188 DOI: 10.18039/ajesi.682020

opinions are discussed in teaching-learning process in the classroom so that parents themselves could do research and obtain knowledge about a subject and, therefore, they could be educated as conscious citizens as well.

While studying the lesson unit "Change and Recognition of Matter" in a $5^{\text {th }}$ Grade science course, the students mentioned some of the news in the media about the swine flu. However, during the discussion, they shared some ideas which were not scientific or based on scientific knowledge such as "the disease is not that bad but it may be fatal for those with lung diseases" and "it was created when human beings got the bird flu". On the other hand, the teacher neither corrected the students' misconceptions nor allowed them to express different opinions about the swine flu. When the students wanted to further discuss the issue, the teacher said, "It's over. Alright. Now, just read your text!" and ended the discussion.

In parallel to the data obtained during the observation sessions, during the semi-structured interviews, the participants mentioned the need to include science and technology-based current issues and problems as a part of citizenship education in science course because they thought socio-scientific topics were significant for equipping students with awareness, sensitivity, and ability to make ethical choices.

As an example of the inclusion of socio-scientific topics in science course, Şükran said, "The proliferation of GM crops, malnutrition because of that, and citizens' recognition of the consequent diseases are the parts of citizenship relevant to scientific knowledge." Genetically modified organisms are used in agriculture in the production of various crops and nutrient contents. However, the use of genetically modified organisms in various foods for infants, children, and adults is a controversial issue. Referring to the public discussion about this issue, Şükran emphasized the need to establish a connection between science course and citizenship education to make decisions about GMO products on the basis of scientific knowledge. 
Murat made a similar comment about socio-scientific topics. He also raised concerns about the use of genetically modified organisms and stated that this was one of the most important contemporary healthy lifestyle problems. Murat said:

It is no longer one of the likely challenges in terms of health today, it has already become the biggest challenge. GMO products and an unhealthy environment are threatening healthy nutrition. These are important nowadays. We do not know the kind of meat we eat anymore. It is the same for fruit and vegetables. We don't know if they use plant hormones. In fact, we know they use plant hormones, but we have to eat. At school, we are trying to raise awareness on these issues.

The participants had limited opinions about socio-scientific topics. Today many current science and technology-based subjects and problems affect social life. However, the participants focused on a single socio-scientific issue. This might be attributed to the fact that news about genetically modified organisms was a current controversial issue at the time of the study. The participants also emphasized the science course's function of raising awareness. This function of science course is important, but it does not effectively work for science course's role with respect to citizenship education. This is because socio-scientific topics require making ethical, moral and value decisions regarding controversial issues affecting social life. The participant teachers, on the other hand, did not address that basic quality of socio-scientific topics.

\section{Scientific Literacy}

With respect to the theme of Scientific Literacy, the participants mentioned the importance of gathering information and data by using various resources, which contributed to the development of basic skills such as making interpretations and inferences. Regarding the topic of Respiratory Organs and Respiratory Diseases in $4^{\text {th }}$ Grade science course, the 
AJESI - Anadolu Journal of Educational Sciences International, 2020; 10(1): 150-188

DOI: 10.18039/ajesi.682020

students discussed their families' and their own concerns about the swine flu and swine flu vaccination. When one of the students asked the teacher, "Would you take swine flu vaccination?" the teacher replied, "I will make my decision after doing research about it". The student's question could be considered important as it questioned the teacher's action as an effective role model citizen. Similarly, the teacher's response was remarkable because it encouraged students to acquire some skills and attitudes as citizens. With respect to citizenship education, science course aims to equip students with the ability to collect data and information from various sources through scientific literacy activities. As a result, students are expected to acquire the competence to make knowledge-based comments. Regarding the conversation above, when the researcher asked the teacher what the purpose of the teacher's response was, the teacher said:

We try to inform them about how to behave in our daily lives and in this age and to equip them with abilities to catch up with current events and interpret them with their families, do research and make inferences about themselves, their future and the world. We should teach them how to make comments based on knowledge rather than rumors or assumptions. Making comments is necessary and so is learning the truth.

The teacher stated that today's conditions required that individuals should be equipped with certain qualities and, therefore, they should possess scientific process skills including research skills so that they could make decisions based on scientific information and data and make inferences about the world and themselves.

In the semi-structured interviews, few of the participants mentioned the need to equip students with scientific literacy by means of citizenship education activities covered in science course. The aim of scientific literacy presented through citizenship education activities covered in the science course is to develop students' skills of analyzing and reasoning based on data so that they could make unbiased and critical assessments. This 
AJESI - Anadolu Journal of Educational Sciences International, 2020; 10(1): 150-188 DOI: 10.18039/ajesi.682020

requires that today's individuals, who are heavily influenced by scientific and technological developments, think critically. Regarding the function of science course in developing scientific literacy with respect to citizenship education, Nuray said, "Well, first, it turns children into researchers. I mean the course presents an experiment or a topic... and what do children do? They turn to research. They do not expect to be given everything by teachers, but they start to add things, too. For example, they can make observations." Nuray added that activities about citizenship education within science course stimulated students' curiosity and guided them into research and, as a result, students made observations by taking responsibility for their learning.

Stressing the importance of equipping students with scientific process skills with respect to citizenship education, Aygül said, “...thinking should be scientific as well. In fact, science is directly related to it. Student' skills of research, inquiry, and investigation should be developed so that they can acquire scientific thinking. And these qualities are already covered among the subjects of science”. Aygül believed that students should acquire scientific thinking skills for citizenship education, which was the basic purpose of science course, and, in this sense, the aim of science course was to provide students with the basic skills of scientific literacy that they needed to possess as citizens.

\section{Rights and Duties}

The theme of Rights and Duties, an attribute of republican approach among the political approaches explaining the concept of citizenship, was discussed in science course with respect to citizenship education. Students' roles in social participation were discussed in the lesson unit Introduction to Matter in $4^{\text {th }}$ Grade science course. About this topic, the teacher said, "Sometimes grown-ups can do very huge mistakes. You will warn your fathers, mothers or neighbors when it is necessary. You should say to them that you have learned the subject 
AJESI - Anadolu Journal of Educational Sciences International, 2020; 10(1): 150-188

DOI: 10.18039/ajesi.682020

this way and tell them to be more careful because they are affecting your future". The teacher also said that they should take responsibility in order to participate effectively in social life and explained that they should be able to warn their close family members and neighbors when necessary to protect their own future and have a sustainable environment.

In another activity about the theme Rights and Duties, regarding global warming and ozone layer depletion in the lesson unit Introduction to Matter in $4^{\text {th }}$ Grade science course, the teacher encouraged students to inform people around them and said, "I remind you that you have a mission as of now". The teacher explained the importance of informing other people with justifications. The topic People Process and Change Matter in the unit Introduction to Matter in $4^{\text {th }}$ Grade science course dealt with the rapid exhaustion of resources by an increase in human population and industrialization. About this issue, the teacher stated that rapid growth in the human population should be controlled and reminded students that they needed to fulfill their responsibilities as citizens. The teacher said,

...in the previous lesson, we talked about your responsibility as citizens. We have to set some rules and certainly apply them. Human reproduction should be taken under control. We must respect the environment, the world. What does that mean? We shouldn't pollute soil, air or water. We should be more careful not only in industrial or agricultural sectors but also in our everyday lives. We have to learn how to keep the environment clean. What should factories do about their waste fumes or liquids? They should treat their wastes before releasing them. As we have always told, people should be sensitive about recycling. What should they do with packages after using them? They should sort them out and contribute to recycling. Farmers also have responsibilities. They should avoid using pesticides as much as possible and keep their use to a minimum level if they have to use pesticides. Once we are careful about these, air, soil and water are cleaned. What should we do now? Our responsibility does not 
AJESI - Anadolu Journal of Educational Sciences International, 2020; 10(1): 150-188

DOI: 10.18039/ajesi.682020

finish here. Once the soil, air, and water are clean, one of the most important things we need to do is increase the number of beings that produce something useful for the environment. What we mean by that are plants. We should forest everywhere. As you know plants are vital for the cycle of life in nature, particularly for the water cycle. Water never vanishes but changes form and location in the world. What we should do then is increasing the number of plants, real producers of the world, to ensure proper water cycle and prevent global warming.

The teacher referred the measures to be taken in order to protect the environment as a duty of citizenship and noted that individuals should be careful not to pollute soil, water, and air in order to protect the environment, sort out the domestic waste for recycling and take part in reforestation activities. The teacher also stated that, as individuals, farmers should be careful about using pesticides and, in institutional level, industrial organizations should take the necessary precautions to protect the environment. Therefore, the teacher highlighted the importance of fulfilling citizenship responsibilities in both individual and institutional level to protect the environment and control global warming.

In the lesson unit Introduction to Matter in $4^{\text {th }}$ Grade science course, the teacher informed the students about the importance of becoming conscious consumers. The teacher drew the students' attention to the use of genetically modified organisms in producing animal food products and stated that these products could cause some problems for human health. The teacher also said that livestock was also genetically modified to increase productivity and some people tried to justify it with the increase in the demand for meat. The teacher added that, as an individual responsibility, we should change our dietary habits and choices and avoid additives used to extend the shelf life of convenience food in supermarkets.

The teacher warned the students to be careful about nutrition as conscious consumers. Reminding the students that they were adult individuals of the future and had a responsibility 
AJESI - Anadolu Journal of Educational Sciences International, 2020; 10(1): 150-188

DOI: 10.18039/ajesi.682020

to correct the mistakes made by today's adults, the teacher clearly emphasized the importance of respecting the environment in production and consumption processes for a livable world. During the semi-structured interviews, regarding the theme of Rights and Duties, the participants mentioned the protection of individual health and becoming conscious consumers and explained how the curriculum of science course addressed these topics with examples.

Relating the theme of Rights and Duties to the protection of individual health, Reyhan said, "The topic about getting to know our bodies, for example, is about learning about one's own body and caring about it. How should we protect our health, what should we do to protect it? A modern person should care about himself or herself ..." Because of the changes in lifestyles and dietary habits, people are faced with several health problems. Therefore, it is essential that individuals gain awareness and education about protecting their own health.

Songül believed that, with respect to citizenship education, science course raised students' awareness about the protection of personal health. She said, “The textbook contains a chapter titled 'Let's Solve the Puzzle of Our Bodies'. Students learn all about respiratory organs and excretory organs. At the end of the chapter, they can tell how to protect their bodies, how to be a healthy person and how to live in a healthy environment." The teacher thought that, with respect to citizenship education, science course informed students not only about the anatomical structure and characteristics of their bodies but also about how to protect personal health and the conditions in which a healthy life can be achieved and maintained. The teacher also noted that students used their knowledge to inform other students and to defend their own rights as an indication of active participation in social life.

Esma drew attention to the problems that failure to protect personal health can cause for the national and individual economy and she said, "It involves health, too. ... I mean how would it contribute to the country's economy if people cared more about their health? Or what about the cost? What economic effects would it have? What social effects would it have? 
AJESI - Anadolu Journal of Educational Sciences International, 2020; 10(1): 150-188

DOI: 10.18039/ajesi.682020

What should we do as citizens?" The teacher considered the protection of personal health not only as "well-being of the individual" but in economic and social terms as well. Therefore, the teacher emphasized that science course reminded students about their responsibilities as citizens.

Another participant, Aziz, mentioned becoming conscious consumers and responsible students as a part of citizenship education within science course. Aziz firstly stated that a healthy and balanced diet was a right that all citizens should have but there were some responsibilities that they should fulfill to have this right. He associated these responsibilities with becoming conscious consumers and said that citizens' responsibilities include checking the expiration date of products, using legally approved products and reporting any problems to the authorities. Also, when explaining the damages caused by products such as cigarette and alcohol, he mentioned the need to give priority to the sacredness of the lives of themselves and other individuals in society.

\section{Discussion and Conclusions}

Education for citizenship is an important educational goal (Duggan \& Gott, 2002; Hurd, 1998; Kolstø, 2001). However, attaining this goal is a major challenge for science education at schools (Mansour, 2009). This is because implementations aimed at combining science and citizenship at school are rare (Pike, 2007). This is also because the answer to the question of how science education will prepare students as citizens is not known (Mansour, 2009). The aim of this study was to come up with an answer to this requirement. The results showed that, as a part of citizenship education, science course could deal with the topics of Science-Technology-Society-Environment (STSE), Scientific Literacy, Socio-Scientific Issues, Rights and Duties. The literature suggests that science course can fulfil its responsibility for citizenship education through the topics of STSE (Lester, Ma, Lee, \& 
AJESI - Anadolu Journal of Educational Sciences International, 2020; 10(1): 150-188 DOI: 10.18039/ajesi.682020

Lambert, 2006; Mansour, 2009; Ratcliffe \& Grace, 2003; Solomon \& Aikenhead, 1994), socio-scientific issues (Cajas, 1999; Driver, Newton \& Osborne, 2000; Sadler, 2004; Zeidler et al., 2005) and scientific literacy (Hurd, 1998; Lee \& Roth, 2003). The relationship between STSE, scientific literacy and socio-scientific issues in terms of implementing citizenship education in science course can be explained by the importance of presenting STSE issues in science course for creating a context for citizenship education. Presenting socio-scientific issues in science course within a context is an educational strategy. In this sense, socioscientific issues could be regarded as a means. The primary aim of covering both STSE topics and socio-scientific issues for citizenship education in science course is to educate citizens who are scientifically literate and can think scientifically. Therefore, these three components should be used in citizenship education in science courses with a holistic approach.

Due to several human and environmental disasters, science has been given the role of a bad guy. Also, science has been perceived as a potential threat to life because of disturbing social changes and ethical problems caused by scientific and technological developments. The increase in the commercialization, industrialization, and militarization of science have once more shown that science is not free from values and it is not neutral. Combination of science and technology within technoscience, the capacity of science to provide information for gaining welfare and power, and the increasing consumption of raw materials for scientific and technological ends have profoundly changed the context of scientific and technological applications in ethical and socio-political terms. For these reasons, there has been a need for revision in science education curricula to respond to these changes (Hodson, 2003). In parallel to the global developments, science education curricula in Turkey have covered a learning domain regarding the topics of STSE (MoNE, 2005). By means of the topics of STSE, the effects of scientific and technological advancements on the cultural structure and the impact of cultural structure on science and technology could be understood more easily (Blades, 
AJESI - Anadolu Journal of Educational Sciences International, 2020; 10(1): 150-188

DOI: 10.18039/ajesi.682020

2006; Mansour, 2009; Solomon \& Aikenhead, 1994). Similarly, gaining a better understanding of how the environment, which is considered to have a passive position, is affected by science and technology and their social implications seems to be more likely by covering the topics of STSE within the context of science education curricula.

This study found that the participants made use of socio-scientific issues in relation to citizenship education. While STSE is defined as "a context for science education" (Yager, 1996, p.6), socio-scientific issues clearly provide a more sophisticated strategy. Socioscientific issues provide an opportunity for students to realize the interaction and connection between science and technology. They also provide a context for individuals to stimulate and improve their ethical and moral developments. For this reason, socio-scientific issues serve science education not only as a context but also as an educational strategy (Driver, Newton, \& Osborne, 2000; Kolstø, 2001; Sadler, 2004; Zeidler et al., 2005). In fact, one way to achieve the projected objectives of STSE education with respect to citizenship education is the use of socio-scientific issues (Pedretti, 1999; Watts, Alsop, Zylbersztajn \& Maria de Silva, 1997 in Pedretti, 2003). When socio-scientific issues are utilized as a context for educational activities, they make it possible to understand how science, technology, society, and environment interact with each other (Ramsey, 1993 in Pedretti, 2003) because socioscientific issues form the foundation of science and technology and they are covered by scientific knowledge. By means of socio-scientific issues, skills related scientific process such as observation; collecting, categorizing and interpreting data; and making inferences could be improved. Socio-scientific issues also involve logical thinking about values and ethical subjects, making choices at individual or social levels, forming thoughts, developing social sensitivity and empathizing.

Scientific problems continue to evolve and grow with their social implications. Considering the growing human population, it is likely that human beings will continue to 
AJESI - Anadolu Journal of Educational Sciences International, 2020; 10(1): 150-188

DOI: 10.18039/ajesi.682020

have socio-scientific problems in the future (Sadler, 2004). In this respect, socio-scientific issues need to be utilized in science and technology courses to prepare students for citizenship education because socio-scientific issues can serve as a means for guiding students into becoming democratic citizens through science and technology education (Cajas, 1999 in Zeidler et al., 2005). By presenting socio-scientific issues in the classroom, educators of science can help achieve the aim of educating students as citizens who are knowledgeable and can think logically (Driver, Newton, \& Osborne, 2000; Kolstø, 2001 in Sadler, 2004). Moreover, socio-scientific issues provide a context for encouraging individuals to think about the implications of science for social life and developing their decision-making and questioning skills. The ability to make ethical choices is an important dimension of active citizenship and citizens need to have an adequate level of scientific literacy to be able to discuss national and global problems (Pike, 2007). Many educators today claim that scientific literacy can be designed in a modern way by means of socio-scientific issues and socioscientific issues are a necessary component of contemporary science and technology classes (Driver, Newton \& Osborne, 2000; Hughes, 2000; Zeidler, Walker, Ackett \& Simmons, 2002).

This study also determined that the topic of Rights and Duties was also emphasized as part of citizenship education activities in science course. The literature does not discuss the theme of Rights and Duties in relation to citizenship education in science course. This situation might have several reasons. Firstly, almost all of the participants stated that they had associated citizenship education with social studies course, but, thanks to this study and the interview questions, they now realized that it was related to science course as well. This situation might be the reason why the participants preferred to establish a connection between Rights and Duties, which is primarily a topic of social studies course, and science course. 
AJESI - Anadolu Journal of Educational Sciences International, 2020; 10(1): 150-188 DOI: 10.18039/ajesi.682020

This study had some limitations. The school where the observational data collected was a middle socio-economic status school. Therefore, the case with lower and upper socioeconomic status schools need to be investigated as well so that the functionality of science course curricula with respect to citizenship education can be analyzed comparatively and analytic generalizations can be obtained. Another limitation of this study was that both teachers who were observed during lessons in the classroom environment to collect data were female teachers. Whether conducting these observations with male teachers would yield different results or not could be investigated in another study. Lastly, the observational data was limited in "Let's Solve the Puzzle of Our Bodies" and "Introduction to Matter" units in $4^{\text {th }}$ grade Science and Technology course and in "Let's Solve the Puzzle of Our Bodies" and "Change and Recognition of Matter" units in $5^{\text {th }}$ grade Science and Technology course. Future research can also examine the teacher training programs' competence to equip teacher candidates with sufficient knowledge to be able to establish connections between science education and citizenship education. Finally, it is also crucial that future science educators' ability to establish connections between science education and citizenship be examined.

\section{Acknowledgement}

This paper dedicated to Prof. Dr. Şefik YAŞAR who spent his whole life to education and science.

\section{References}

Aikenhead, G. S. (1990). Scientific/technological literacy, critical reasoning and classroom practice. In S. P. Norris, \& L. M. Phillips (Eds.), Foundations of literacy policy in Canada (pp. 127-145). Calgary, AB, Canada: Detselig Enterprises. 
AJESI - Anadolu Journal of Educational Sciences International, 2020; 10(1): 150-188 DOI: 10.18039/ajesi.682020

Anderson, C., Avery, P. G., Pederson, P. V., S. S., Elizabeth, \& Sullivan, J. L. (1997). Divergent perspectives on citizenship education: A q-method study and survey of social studies teachers. American Educational Research Journal, 34(2), 333-364.

Barbosa, R. (2004). Cooperating in constructing knowledge: case studies from chemistry and citizenship. International Journal of Science Education, 26(8), 935-949.

Bingle, W. H. \& Gaskell, P. J. (1994). Scientific literacy for decision making and the social construction of scientific knowledge. Science Education, 72, 185-201.

Birzéa, C., Kerr, D., Mikkelsen, R., Froumin, I., Losito, B., Pol, M., Sardoc, M., Harrison, C. \& Baumgartl, B. (2004). All-European study on education for democratic citizenship policies. Retrieved from http://www.edchreturkeyeu.coe.int/Source/Resources/Pack/AllEuropeanStudyEDCPolicies_En.pdf

Blades, D. W. (2006). Levinas and an ethics for science education. Educational Philosophy and Theory, 38(5), 647-664.

Bottcher, F. \& Meisert, A. (2013). Effects of direct and indirect instruction on fostering decision-making competence in socioscientific issues. Research in Science Education, 43, 479-506.

Cajas, F. (1999). Public understanding of science: Using technology to enhance school science in everyday life. International Journal of Science Education, 21, 765-773.

Chamberlin, R. (2003). Citizenship? Only if you haven't got a life: Secondary school pupils' views of citizenship education. International Journal of Research \& Method in Education, 26(2), 87-97.

Davies, I. \& Thorpe, T. (2003). Thinking and acting as citizens. In A. Ross and C. RolandLévy (Eds.), Political Education in Europe (pp. 34-52). Stoke on Trent: Trentham.

Davies, I. (2004). Science and citizenship education. International Journal of Science Education, 26(14), 1751-1763. 
AJESI - Anadolu Journal of Educational Sciences International, 2020; 10(1): 150-188

DOI: 10.18039/ajesi.682020

Driver, R., Newton, P., \& Osborne, J. (2000). Establishing the norms of scientific argumentation in classrooms. Science Education, 84, 287-312.

Duggan, S. \& Gott, R. (2002). What sort of science education do we really need? International Journal of Science Education, 24(7), 661-679.

Ersoy., A. F. (2007). Sosyal bilgiler derslerinde öğretmenlerin etkili vatandaşlık ĕgitimi uygulamalarına ilişkin görüşleri. Yayınlanmamış Doktora Tezi. Eskişehir: Anadolu Üniversitesi Eğitim Bilimleri Enstitüsü.

Hicks, D. (2001). Re-examining the future: The challenge for citizenship education. Educational Review, 53(3), 229-240.

Hodson, D. (2003). Time for action: Science education for an alternative future. International Journal of Science Education, 25(6), 645-670.

Hoge, J. D. (2002). Character education, citizenship education, and the social studies. The Social Studies, 93(3), 103-108.

Hoskins, B. (2006). Draft framework on indicators for active citizenship. Ispra: CRELL.

Hughes, G. (2000). Marginalization of socioscientific material in science-technology-society science curricula: Some implications for gender inclusivity and curriculum reform. Journal of Research in Science Teaching, 37, 426-440.

Hurd, P. D. (1998). Scientific literacy: New minds for a changing world. Science Education, 82(3), 407-416.

Ideland, M., Malmberg, C. \& Winberg, M. (2011). Culturally equipped for socio scientific issues? A comparative study on how teachers and students in mono and multiethnic schools handle work with complex issues. International Journal of Science Education, 33(13), 1835-1859.

Jenkins, E. W. (1992). School science education: Towards a reconstruction. Journal of Curriculum Studies, 24, 229-246. 
AJESI - Anadolu Journal of Educational Sciences International, 2020; 10(1): 150-188

DOI: 10.18039/ajesi.682020

Kerr, D., Keating, A. \& Ireland, E. (2009). Pupil assessment in citizenship education: Purposes, practices and possibilities. Slough: NFER/CIDREE.

Khishfe, R. (2014). Explicit nature of science and argumentation instruction in the context of socioscientific issues: An effect on student learning and transfer. International Journal of Science Education, 36(6), 974-1016.

Kolstø, S. (2001). Scientific literacy for citizenship: Tools for dealing with the science dimension of controversial socioscientific issues. Science Education, 85(3), 291-310.

Layton, D., Jenkins, E., Macgill, S., \& Davey, A. (1993). Inarticulate science? Perspectives on the public understanding of science and some implications for science education. Nafferton: Studies in Education.

Lee, S. \& Roth, W. M. (2003). Science and the "good citizen": Community-based scientific literacy. Science, Technology, \& Human Values, 28(3), 403-424.

Lester, B. T., Ma, L., Lee, O., \& Lambert, J. (2006). Social activism in elementary science education: A science, technology, and society approach to teach global warming. International Journal of Science Education, 28(4), 315-339.

Levinson, R., \& Turner, S. (2001). Valuable lessons. London: Wellcome Trust.

Mansour, N. (2009). Science-technology-society (STS): A new paradigm in science education. Bulletin of Science Technology \& Society, 29(4), 287-297.

Miles, M. B. \& Huberman, A. M. (1994). An expanded source book: Qualitative data analysis ( $2^{\text {nd }}$ Ed.). London: Sage Publications.

Miller, J. D. (2006). Civic scientific literacy in Europe and the United States. A paper presented to the annual meeting of the World Association for Public Opinion Research, Montreal, Canada.

Ministry of National Education [MoNE]. (2005). Fen ve teknoloji dersi programı: İlkögrretim 4-5. sınıf. Ankara: Devlet Kitapları Müdürlüğü Basım Evi. 
AJESI - Anadolu Journal of Educational Sciences International, 2020; 10(1): 150-188

DOI: 10.18039/ajesi.682020

Nelson, J. \& Kerr, D. (2006). Active citizenship in INCA countries: definitions, policies, $\begin{array}{lll}\text { practices and } & \text { outcomes. } & \text { Retrieved }\end{array}$ https://nzcurriculum.tki.org.nz/content/download/654/4291/file/Active_Citizenshi p_Report.pdf

Osborne, J. (2000). Science and citizenship. In M. Monk \& J. Osborne (Eds.) Good Practice in Science Teaching: What Research Has to Say (pp. 225-240). Buckingham: Open University Press.

Özden, M \& Yaşar, Ş. (2009). İlköğretim 4. ve 5. sınıflar fen ve teknoloji dersi programının vatandaşlık ĕgitimi bakımından incelenmesi. VIII. Ulusal Sınıf Öğretmenliği Eğitim Sempozyumu’nda sunulan bildiri. ESOGÜ Eğitim Fakültesi, Eskişehir.

Patton, M. Q. (2001). Qualitative research and evaluation methods. (3 ${ }^{\text {rd }}$ Ed.). Thousand Oaks: Sage.

Pedretti, E. (1999). Decision making and STS education: Exploring scientific knowledge and social responsibility in schools and science centers through an issue-based approach. School Science and Mathematics, 99, 174-181.

Pedretti, E. (2003). Teaching science, technology, society and environment education: Preservice teachers' philosophical and pedagogical landscapes. In D. L. Zeidler (Ed.), The role of moral reasoning on socioscientific issues and discourse in science education (pp.219-239). London: Kluwer Academic Publishers.

Pike, M. A. (2007). Values and visibility: The implementation and assessment of citizenship education in schools. Educational Review, 59(2), 215-229.

Punch, K. F. (2005). Sosyal araştırmalara giriş: Nicel ve nitel yaklaşımlar. (Çev. D. Bayrak, H. B. Arslan, \& Z. Akyüz). Ankara: Siyasal Kitabevi.

Qualifications and Curriculum Authority. (QCA, 1998). Education for citizenship and the teaching of democracy in schools. London: QCA. 
AJESI - Anadolu Journal of Educational Sciences International, 2020; 10(1): 150-188

DOI: 10.18039/ajesi.682020

Ratcliffe, M. \& Grace, M. (2003). Science education for citizenship: Teaching socio-scientific issues. Maidenhead: Open University Press.

Roth, W. M., \& Dêsautels, J. (2004). Educating for citizenship: Reappraising the role of science education. Canadian Journal of Science, Mathematics and Technology Edaucation, 4(2), 149-168.

Sadler, T. D. (2004). Informal reasoning regarding socioscientific issues: A critical review of research. Journal of Research in Science Teaching, 41(5), 513-536.

Sadler, T. D., Barab, S. A., \& Scott, B. (2007). What do students gain by engaging in socioscientific inquiry? Research in Science Education, 37, 371-391.

Solomon, J., \& Aikenhead, G. S. (1994). STS education: International perspectives on reform. New York: Teachers College Press.

Solomon, J. (1993). Teaching science, technology, society. Buckingham, UK: Open University Press.

Stake, R. E. (1995). The art of case study research. London: Sage Publications.

Stake, R. E. (2005). Qualitative case studies. In N. K. Denzin \& Y. S. Lincoln (Eds.), The sage handbook of qualitative research (pp.443-466). London: Sage.

Yager, R. E. (1996). History of science/technology/society as reform in the United States. In R. E. Yager (Ed.), Science/technology/society as reform in science education (pp. 315). Albany, NY: State University of New York Press.

Yıldırım A. \& Şimşek, H. (2006). Sosyal bilimlerde nitel araştırma yöntemleri. Ankara: Seçkin Yayıncılık.

Yin, R. K. (2015). Case study research: Design and methods. ( $5^{\text {th }}$ ed.). LA: SAGE.

Yin, R. K. (2003). Case study research: Design and methods. ( $3^{\text {rd }}$ ed.). Thousand Oaks: SAGE. 
AJESI - Anadolu Journal of Educational Sciences International, 2020; 10(1): 150-188 DOI: 10.18039/ajesi.682020

Zeidler, D. L., Sadler, T. D., Simmons, M. L., \& Howes, E. V. (2005). Beyond STS: A research-based framework for socioscientific issues education. Science Education, 89, 357-377.

Zeidler, D. L., Walker, K. A., Ackett, W. A., \& Simmons, M. L. (2002). Tangled up in views: Beliefs in the nature of science and responses to socioscientific dilemmas. Science Education, 86, 343-367.

Zembylas, M. (2005). Science education: For citizenship and/or for social justice? Journal of Curriculum Studies, 37(6), 709-722. 